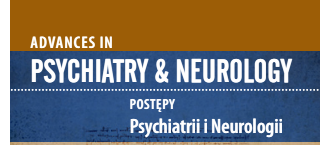

Correspondence to/

Adres do korespondencji:

Halina Sienkiewicz-Jarosz

$1^{\text {st }}$ Department of Neurology

Institute of Psychiatry and Neurology

9 Sobieskiego Str.

02-679 Warsaw, Poland

e-mail: jarosz@ipin.edu.pl

Submitted/Otrzymano: 23.04.2020

Accepted/Przyjęto do druku: 03.06.2020

\section{NEUROLOGIST'S ROLE DURING THE SARS-COV-2 PANDEMIC}

\author{
ROLA NEUROLOGA PODCZAS PANDEMII \\ SARS-COV-2
}

\author{
Ewelina Bucior, Halina Sienkiewicz-Jarosz, \\ Magdalena Konopko \\ $1^{\text {st }}$ Department of Neurology, Institute of Psychiatry and Neurology, Warsaw, Poland \\ I Klinika Neurologiczna, Instytut Psychiatrii i Neurologii, Warszawa, Polska
}

\begin{abstract}
Purpose: The article discusses the role of a neurologist during the SARS-CoV-2 pandemic with the aim of spreading the knowledge about possible neurological symptoms of COVID-19 among physicians.

Views: COVID-19, caused by SARS-COV-2, is a new, highly contagious pandemic disease transmitted mainly by way of respiratory droplets. The virus mostly attacks the respiratory system, although in some cases, the nervous system is also affected. Either right at the outset of the disease or in its later stages, patients with COVID-19 may develop neurological symptoms. Smell and/or taste problems and myopathy are the initial symptoms observed even without the coexistence of respiratory complaints. Patients with suspected or confirmed COVID-19 may also experience acute cerebrovascular events. Hypertension and diabetes stand out as the most common comorbidities but many patients also have coexisting neurological disorders. Neurologists may come into contact with infected patients while working in outpatient clinics, emergency rooms or hospital wards.

Conclusions: The awareness of SARS-COV-2's neurotropism helps neurologists make a correct diagnosis early in a course of disease and apply isolation in order to prevent the deterioration of clinical symptoms and prevent further transmission of the virus. Close cooperation between neurologists and specialists in infectious diseases is the basic form of care for SARS-CoV-2 infected patients with concomitant neurological diseases. NeuroCovid units that provide care for such patients might be coming in our near future.
\end{abstract}

Key words: COVID-19, SARS-CoV-2, coronavirus, neurological symptoms.

\title{
Streszczenie
}

Cel: Przedstawienie roli neurologa w czasach pandemii SARS-CoV-2 oraz poszerzenie wiedzy lekarzy o możliwych objawach neurologicznych w przebiegu COVID-19.

Poglądy: Choroba COVID-19 wywoływana przez wirusa SARS-COV-2 jest nową, wysoce zaraźliwą chorobą pandemiczną przenoszoną głównie drogą kropelkową. Koronawirus infekuje najczęściej układ oddechowy, ale u części zakażonych pacjentów obserwuje się również zajęcie układu nerwowego. Pacjenci z COVID-19 mogą rozwinąć objawy neurologiczne na początku choroby lub na jej późniejszym etapie. Coraz częściej obserwuje się początkowe objawy w postaci zaburzeń węchu, smaku czy miopatii bez współistnienia poważnych objawów ze strony układu oddechowego. U pacjentów z podejrzeniem lub potwierdzeniem COVID-19 zdarzają się też ostre incydenty naczyniowo-mózgowe. Nadciśnienie tętnicze i cukrzyca wyróżniają się jako najczęściej stwierdzane choroby towarzyszące zakażeniu, wielu pacjentów ma także neurologiczne choroby współistniejące. Neurolodzy z pewnością mogą się spodziewać kontaktu z zainfekowanymi pacjentami podczas pracy w poradni, izbie przyjęć czy na oddziale szpitalnym.

Wnioski: Świadomość pewnego rodzaju neurotropizmu SARS-COV-2 daje przewagę neurologom w formułowaniu prawidłowej diagnozy, rozpoczynaniu wczesnego leczenia i izolacji, co zapobiega pogorszeniu stanu klinicznego pacjentów i rozprzestrzenianiu się wirusa. Ścisła współpraca pomiędzy neurologami a specjalistami chorób zakaźnych to podstawa opieki nad pacjentami zakażonymi SARS-CoV-2 ze współistniejącymi chorobami neurologicznymi. Możliwe, że oddziały NeuroCovid to nasza niedaleka przyszłość.

Słowa kluczowe: COVID-19, SARS-CoV-2, koronawirus, objawy neurologiczne. 


\section{INTRODUCTION}

SARS-CoV-2 (severe acute respiratory syndrome coronavirus 2) is a sheath virus with a single-stranded RNA genome and a characteristic "crown"-like envelope visible under the electron microscope. By 2019, six viruses belonging to the coronavirus family that cause infections in humans had been identified; four of them (229E, OC43, NL63, HKU1) are the cause of benign respiratory infections in humans and animals [1]; the other two, i.e. severe acute respiratory coronavirus (SARS-CoV) and the Middle East respiratory coronavirus (MERS-CoV), may lead to life-threatening acute respiratory failure [2]. According to the World Health Organization (WHO) data, the SARS epidemic in 2002-2003 caused the death of 916 people, whereas it is MERS-CoV that has been responsible for an acute infectious disease called Middle Eastern Respiratory Failure Syndrome. Since September 2012, when it was first isolated, MERS-CoV has been found in over 40 people, half of whom died [3]. The SARS-CoV-2 virus is the seventh known human virus of the coronavirus family. The virus induces severe acute respiratory failure syndrome, a disease known as COVID-19 (coronavirus disease-19) [4]. The name COVID-19 was coined by World Health Organization. The "CO" in the name stands for corona, "VI" for virus, and "D" for disease; the number 19 indicates the year of the outbreak. The new coronavirus was identified by the WHO as the cause of the global pandemic on 11 March 2020. The virus is mainly transmitted by respiratory droplets and through direct contact with an infected person. It has been confirmed that a live virus and viral nucleic acid have been detected in human faeces [5]. Therefore, there is speculation that the gastrointestinal tract may be another route of virus transmission.

\section{COVID DIAGNOSTICS}

Currently, the gold standard in the diagnostics of SARS-CoV-2 infection is the examination of virus genetic material in the samples taken from the patient's upper or lower airways. The tests are performed by molecular methods recommended by WHO (real time RT-PCR). Serological methods are another way to diagnose infections, consisting in detecting antibodies specific to viral proteins which the body produces in response to an infection in the blood serum. There are no established standards for the interpretation of these tests. Notably, the result of the test for the detection of antibodies may be negative in the early stages of infection due to the phenomenon of serological window. Also, the sensitivity of molecular testing is not $100 \%$, so physicians need to remain vigilant in the observation of patients; sometimes repeat testing

\section{WPROWADZENIE}

SARS-CoV-2 (severe acute respiratory syndrome coronavirus 2) jest wirusem osłonkowym, którego genom stanowi jednoniciowe RNA z charakterystyczną otoczką przypominającą „koronę”, widoczną wokół wirionów w mikroskopie elektronowym. Do 2019 roku poznano sześć wirusów należących do rodziny koronawirusów powodujących zakażenia u ludzi. Cztery z nich (229E, OC43, NL63, HKU1) są przyczyną łagodnych zakażeń układu oddechowego ludzi i zwierząt [1]. Dwa pozostałe, czyli wirus SARS-CoV (severe acute respiratory syndrome coronavirus) i MERS-CoV (Middle East respiratory syndrome coronavirus), mogą prowadzić do zagrażającej życiu ostrej niewydolności oddechowej [2]. Według danych Światowej Organizacji Zdrowia (World Health Organization - WHO) epidemia SARS w latach 2002-2003 spowodowała śmierć 916 osób. MERSCoV jest odpowiedzialny za ostrą chorobę zakaźną zwaną bliskowschodnim zespołem niewydolności oddechowej. Od września 2012 roku, kiedy to po raz pierwszy został opisany, wykryto go u ponad 40 osób, z czego połowa zmarła [3]. Wirus SARS-CoV-2 jest siódmym poznanym wirusem $\mathrm{z}$ rodziny koronawirusów zakażającym człowieka. Wirus ten wywołuje zespół ciężkiej ostrej niewydolności oddechowej - jednostkę chorobową nazwaną COVID-19 (coronavirus disease-19) [4]. Nazwa COVID-19 została ogłoszona przez WHO. „CO” w nazwie oznacza koronę (corona), „VI” - wirusa (virus), „D” - chorobę (disease), a liczba 19 wskazuje rok pojawienia się wirusa - 2019. Nowy koronawirus został uznany przez WHO za przyczynę światowej pandemii 11 marca 2020 roku. Główną drogą transmisji dla wirusa jest droga kropelkowa i bezpośredni kontakt. Potwierdzono również, że żywego wirusa i wirusowy kwas nukleinowy można wykryć w kale ludzkim [5]. Spekuluje się zatem, że przewód pokarmowy może być kolejną drogą przenoszenia wirusa.

\section{DIAGNOSTYKA COVID}

Obecnie złotym standardem $\mathrm{w}$ diagnostyce zakażeń SARS-CoV-2 pozostaje badanie materiału genetycznego wirusa w próbkach pobranych z górnych lub dolnych dróg oddechowych pacjenta. Testy są wykonywane metodami molekularnymi rekomendowanymi przez WHO (RT-PCR w czasie rzeczywistym). Metody serologiczne są innym sposobem diagnostyki zakażeń. Polegają na wykrywaniu w surowicy ludzkiej przeciwciał swoistych względem białek wirusowych, które organizm wytworzył w odpowiedzi na zakażenie. Nie ma jeszcze ustalonych standardów interpretacji tych badań. Należy podkreślić, że wykrywanie przeciwciał we wczesnej fazie infekcji może dać wynik ujemny ze względu na zjawisko okienka serologicznego. Testy molekularne nie mają 100\% czułości, lekarze muszą zachować czujność i obserwować pacjentów, czasem wymagane jest również powtórzenie testu. Zespół badaczy 
may be necessary. A team of researchers supervised by Jin reports that a person infected with SARS-CoV-2 may be asymptomatic or symptomatic, and laboratory results do not always show significant abnormalities, neither do CT scans of the chest. In rare cases, the result of the molecular test is also negative. According to the consensus reached by Chinese researchers, the diagnosis is confirmed with characteristic changes in chest CT scans or with a positive IgM test for the presence of the virus [6].

\section{Angiotensin II convertase as a receptor for SARS-CoV-2}

The ACE-2 protein (angiotensin II convertase, angiotensin-converting enzyme) is a functional receptor of the S protein of the SARS-CoV-2 virus, and its role- among other things- is to regulate small arterial spasms and blood pressure $[7,8]$. The use of ACE inhibitors may lead to the increased expression of ACE-2, making cells more susceptible to viral infection. Clinical trials are underway to test this hypothesis. ACE2 is present in the nervous system and also skeletal muscles and the heart muscle [9]. This significantly increases the likelihood that strokes may be directly or indirectly linked to SARS-CoV-2 infection, and encephalitis may occur as its complication [10]. Autopsies of COVID-19 patients showed that the nervous tissue was swollen and degenerated [11]. SARS-CoV-2 can get into the central nervous system via blood vessels or retrograde neuronal pathways, which may be supported by the fact that some patients showed an olfactory symptoms [12]. In animal models, both ACE inhibitors and angiotensin receptor antagonists cause increased expression of ACE- 2 receptors in myocardial cells. These results have raised concerns that the use of drugs from those groups might increase the risk of infection, so they might have to be discontinued to minimize the risk. Finally, cardiological associations around the world recommended that angiotensin receptor antagonists were not discontinued as there was no experimental or clinical evidence that would confirm benefits of doing otherwise [13].

\section{COVID-19 symptoms}

The incubation period of the virus is usually 3-14 days, although the longest reported is 24 days. The symptoms usually appear between the $2^{\text {nd }}$ and $14^{\text {th }}$ day after catching the infection [14]. Initially these are mild, but their severity increases with time. The course of COVID-19 varies from asymptomatic or mild respiratory infections to severe pneumonia with acute respiratory failure syndrome and/or multi-organ failure. According to Wu et al., about $81 \%$ of all infections are mild and only $5 \%$ are severe, as in respirato- pod kierownictwem Jin podaje, że osoba zakażona SARSCoV-2 może prezentować się bezobjawowo lub objawowo, a wyniki badań laboratoryjnych nie zawsze są nieprawidłowe, podobnie jak wyniki tomografii komputerowej klatki piersiowej. W rzadkich przypadkach uzyskiwano negatywny wynik testu molekularnego. Zgodnie $\mathrm{z}$ konsensusem opublikowanym przez chińską grupę badaczy diagnozę można potwierdzić, jeśli widoczne są charakterystyczne zmiany w tomografii komputerowej klatki piersiowej lub uzyskano dodatni test IgM na obecność wirusa [6].

\section{Konwertaza angiotensyny II jako receptor dla SARS-CoV-2}

Białko ACE-2 (konwertaza angiotensyny II, angiotensin-converting enzyme) jest funkcjonalnym receptorem dla białka $\mathrm{S}$ wirusa SARS-CoV-2, a jego rolą jest m.in. regulacja skurczów drobnych naczyń tętniczych i ciśnienia krwi $[7,8]$. Stosowanie inhibitorów ACE prowadzi do zwiększonej ekspresji ACE-2, czyniąc komórki bardziej podatnymi na infekcję wirusem. Trwają badania kliniczne w celu przetestowania tej hipotezy. ACE-2 jest obecna w wielu narządach, w tym w układzie nerwowym, mięśniach szkieletowych czy mięśniu sercowym [9]. Istotnie zwiększa to prawdopodobieństwo, że udary mózgu mogą być pośrednio lub bezpośrednio związane z zakażeniem SARS-CoV-2, a zapalenie mózgu może być jego powikłaniem [10]. Wyniki autopsji pacjentów z COVID-19 wykazały, że tkanka nerwowa była obrzęknięta i zwyrodniała [11]. SARS-CoV-2 może dostać się do ośrodkowego układu nerwowego drogą naczyń krwionośnych lub wsteczną drogą neuronalną, co może być poparte faktem, że niektórzy pacjenci mieli zaburzenia węchu [12]. W badaniach na modelach zwierzęcych zarówno inhibitory ACE, jak i antagoniści receptora angiotensyny powodują zwiększoną ekspresję receptorów ACE-2 w komórkach mięśnia sercowego. Wyniki wzbudziły obawę, czy stosowanie leków z powyższych grup nie zwiększa ryzyka zakażenia u chorych je przyjmujących, a więc czy nie rozważyć odstawiania tych leków w celu zminimalizowania tego ryzyka. Ostatecznie jednak towarzystwa kardiologiczne na świecie zalecają kontynuację stosowania inhibitorów konwertazy angiotensyny, ponieważ obecnie nie ma dowodów eksperymentalnych ani klinicznych wykazujących korzyści $\mathrm{z}$ odstawienia tych leków [13].

\section{Objawy COVID-19}

Okres inkubacji wirusa wynosi zazwyczaj 3-14 dni, ale najdłuższy opisany to 24 dni. Objawy pojawiają się zwykle między 2. a 14. dniem po zakażeniu [14]. Początkowo są łagodne, ich nasilenie narasta z czasem. Przebieg zakażeń COVID-19 jest zróżnicowany: od bezobjawowego, przez łagodną infekcję układu oddechowego, po ciężkie zapalenie płuc z zespołem ostrej niewydolności oddechowej i/lub niewydolnością wielonarządową. Według Wu i wsp. ok. $81 \%$ zakażeń ma łagodny przebieg, a 5\% przebiega 
ry failure, septic shock and multi-organ failure [15]. In the Wang et al. study, typical symptoms included fever, which occurred in $98.6 \%$ of patients, fatigue in $69.6 \%$, and dry cough in 59\% [16]. Guang et al. analysed the clinical data of 1099 people with a confirmed SARS-CoV-2 infection in China. Fever was present in $43.8 \%$ of patients on admission to hospital, and in $88.7 \%$ during hospitalization. The second most frequent symptom was coughing, which was reported in $67.8 \%$ of patients, followed by nausea and vomiting in $5 \%$ and diarrhea in 3.8\% [14]. Moreover, some patients complained of sore throat, abdominal pain and conjunctivitis. It is recommended that patients who display any of these symptoms, even if in a mild form, should be tested for COVID-19 [6]. According to Guang et al., the most common abnormalities found in laboratory tests were leukopenia (33.7\%), lymphopenia (83.2\%) and thrombocytopenia (36.2\%). Most patients had elevated CRP, AlAT, AspAT, creatine kinase and D-dimers. Abnormalities in CT chest scans were also observed in the majority of patients (86.2\%); the reports mentioned milky glass image (5.4\%) and bilateral non-uniform shading (51.8\%). Among the reported comorbidities were chronic obstructive pulmonary disease, diabetes, arterial hypertension, coronary artery disease, cerebrovascular disease, hepatitis B, cancer, chronic kidney disease or immunodeficiency [14].

\section{Neurological symptoms in SARS-CoV-2 patients}

Several acute neurological syndromes have been associated with coronaviruses so far. The SARS-CoV virus has been detected in the cerebrospinal fluid of a patient with encephalitis and acute respiratory failure syndrome [17]. It has been shown that MERS-CoV may cause a severe form of acute disseminated encephalomyelitis with vasculitis [18]. Moreover, Guillain-Barré syndrome and acute necrotic hemorrhagic encephalopathy have been reported in the course of coronavirus infection [19]. Neurological symptoms were also observed in patients with COVID-19 [12, 20, 21]. Iranian researchers reported that every fourth infected patient displayed neurological symptoms [20], and according to a Chinese study more than one third of patients presented symptoms in the central and peripheral nervous system, although skeletal muscle damage was also reported [12]. Among the most common central nervous system symptoms were dizziness and headache, disorders of consciousness, cerebrovascular incidents, ataxia and convulsions. Patients with peripheral nervous system symptoms reported distorted senses of taste and smell and, less frequently, visual impairment or neuralgia (Table 1). It has been also stressed that anosmia is a common early symptom of COVID-19 disease [12]. w sposób ciężki jako niewydolność oddechowa, wstrząs septyczny i niewydolność wielonarządowa [15]. W badaniu Wanga i wsp. typowe objawy obejmowały gorączkę, która wystąpiła u 98,6\% pacjentów, zmęczenie - u 69,6\%, i suchy kaszel - u 59\% [16]. Guang i wsp. analizowali dane kliniczne 1099 osób z potwierdzonym zakażeniem SARS-CoV-2 w Chinach. Gorączka występowała u 43,8\% badanych przy przyjęciu do szpitala, a podczas hospitalizacji już u $88,7 \%$. Drugim co do częstości występowania objawem był kaszel notowany u 67,8\% pacjentów, a kolejnymi - nudności i wymioty - u 5\%, biegunka - 3,8\% [14]. Ponadto u niektórych pacjentów występował ból gardła, ból brzucha, biegunka i zapalenie spojówek. Dlatego jeśli u pacjenta występuje którykolwiek z tych objawów, nawet jeśli objawy są łagodne, zaleca się badanie w kierunku COVID-19 [6]. Według Guanga i wsp. najczęstszymi nieprawidłowościami stwierdzanymi w badaniach laboratoryjnych były: leukopenia $(33,7 \%)$, limfopenia (83,2\%) i trombocytopenia (36,2\%). Większość chorych miała podwyższone miana CRP, AlAT, AspAT, kinazy kreatynowej oraz D-dimerów. U większości zakażonych osób obserwowano nieprawidłowości w badaniu tomografii komputerowej klatki piersiowej (86,2\%). Przede wszystkim opisywany był obraz mlecznej szyby $(5,4 \%)$ oraz obustronne niejednolite zacienienia $(51,8 \%)$. Wśród wymienianych chorób współistniejących powtarzały się przewlekła choroba obturacyjna płuc, cukrzyca, nadciśnienie tętnicze, choroba wieńcowa, choroba naczyń mózgowych, wirusowe zapalenie wątroby typu B, nowotwór, przewlekła choroba nerek czy niedobór odporności [14].

\section{Objawy neurologiczne u zakażonych wirusem SARS-CoV-2}

Dotąd $\mathrm{z}$ koronawirusami powiązano kilka ostrych zespołów neurologicznych. Wirus SARS-CoV został wykryty w płynie mózgowo-rdzeniowym pacjenta $\mathrm{z}$ zapaleniem mózgu i zespołem ostrej niewydolności oddechowej [17]. MERS-CoV może powodować ciężkie ostre rozsiane zapalenie mózgu i rdzenia z zapaleniem naczyń [18]. W przebiegu zakażenia koronawirusami opisano ponadto zespół Guillaina-Barrégo i ostrą martwiczą encefalopatię krwotoczną [19]. U pacjentów z COVID-19 zaobserwowano też objawy neurologiczne $[12,20,21]$. Irańscy badacze stwierdzili, że co u czwartego pacjenta zauważono objawy neurologiczne [20], a według chińskiego badania ponad jedna trzecia pacjentów prezentowała objawy w zakresie ośrodkowego i obwodowego układu nerwowego, ale dochodziło również do uszkodzenia mięśni szkieletowych [12]. Najczęstszymi dolegliwościami ze strony ośrodkowego układu nerwowego były zawroty głowy i ból głowy. Inne to: zaburzenia świadomości, incydenty naczyniowo-mózgowe, ataksja czy drgawki. Pacjenci z objawami dotyczącymi obwodowego układu nerwowego zgłaszali najczęściej zaburzenia smaku i węchu oraz rzadziej upośledzenie wzroku czy neuralgie (tab. 1). 
The neurologist's role during the SARS-COV-2 pandemic

Rola neurologa podczas pandemii SARS-COV-2

Table 1. The most common neurological symptoms of SARS-CoV-2 infection ( $n=214)$ based on Mao et al., 2020 (12) Tabela 1. Najczęstsze objawy neurologiczne zakażenia SARS-CoV-2 ( $n=214)$ na podstawie Mao i wsp. , 2020 (12)

\begin{tabular}{|l|c|}
\hline Central nervous system/Ośrodkowy układ nerwowy & $\mathbf{n = 5 3}(\mathbf{2 4 . 8 \% )}$ \\
\hline Dizziness/Zawroty głowy & $36(16.8 \%)$ \\
\hline Headaches/Bóle głowy & $28(13.1 \%)$ \\
\hline Consciousness disturbances/Zaburzenia świadomości & $16(7.5 \%)$ \\
\hline Acute cerebrovascular accidents/Ostre incydenty naczyniowo-mózgowe & $6(2.8 \%)$ \\
\hline Ataxia/Ataksja & $1(0.5 \%)$ \\
\hline Convulsions/Drgawki & $1(0.5 \%)$ \\
\hline Peripheral nervous system/Obwodowy układ nerwowy & $\mathbf{n = 1 9 ( 8 . 9 \% )}$ \\
\hline Taste disorders/Zaburzenia smaku & $12(5.6 \%)$ \\
\hline Olfactory disorders/Zaburzenia węchu & $11(5.1 \%)$ \\
\hline Vision disorders/Zaburzenia wzroku & $3(1.4 \%)$ \\
\hline Neuralgias/Neuralgie & $5(2.3 \%)$ \\
\hline
\end{tabular}

In fact Italian researchers found the occurrence of taste or smell disturbances in $33.9 \%$ of examined patients ( $n=59$ ), whereas they found changes in the sense of taste occurring most often prior to hospitalization (91\%). Taste and smell disorders after hospitalization were equally frequent, with women complaining of the occurrence of such problems more frequently [22]. The difference between the loss of the sense of smell in the course of SARS-CoV-2 infection and normal upper respiratory tract infection lies in the lack of a co-occurrence of nasal mucosa congestion in the case of SARS-CoV-2 infection [23]. The ACE-2 protein, which causes SARS-CoV-2 to bind with cells, has been found to be present in large quantities on the epithelial cells of the oral cavity mucosa [24]. This may explain the pathophysiological mechanism underlying the sense of taste and smell disturbances in infected people. Some patients with COVID-19 have also experienced skeletal muscle damage, defined as skeletal muscle pain accompanied by elevated serum creatine kinase levels above 200 U/1 [14]. In fact, rhabdomyolysis may be a late complication of the infection [25]. In patients with symptoms of muscle damage, screening for SARS-CoV-2 is recommended. In such cases intensified nutritional support is also recommended, in addition to active treatment of COVID-19.

As part of their daily practice, neurologists treat many patients with autoimmune syndromes such as multiple sclerosis, myasthenia gravis or optic neuritis with immunosuppressive therapies. The patients should be advised to take additional precautions to prevent exposure to the virus, or to have their doses of immunosuppressive drugs re-examined. Getting acquainted with the recommendations developed by the group of experts of the Multiple Sclerosis and Neuroimmu-
Podkreśla się, że anosmia jest częstym i wczesnym objawem choroby COVID-19 [12]. Włoscy badacze także stwierdzili występowanie zaburzeń smaku lub węchu u 33,9 \% badanych $(n=59)$. Zmiany w zakresie zmysłu smaku pojawiały się u ich pacjentów najczęściej przed hospitalizacją (91\%), podczas gdy zaburzenia zmysłu smaku i węchu po pobycie szpitalnym występowały już z równą częstością. Kobiety zgłaszały częściej występowanie takich zaburzeń [22]. Różnica między utratą węchu w przebiegu zakażenia SARS-CoV-2 i zwykłej infekcji górnych dróg oddechowych polega na braku współwystępowania przekrwienia błony śluzowej nosa w przypadku zakażenia SARS-CoV-2 [23]. Białko ACE-2, dzięki któremu SARS-CoV-2 łączy się z komórkami, występuje w dużych ilościach na komórkach nabłonkowych błony śluzowej jamy ustnej [24]. Może to tłumaczyć mechanizm patofizjologiczny leżący u podłoża zaburzeń zmysłu smaku i węchu u pacjentów zakażonych SARS-CoV-2. Niektórzy pacjenci z COVID-19 mogą odczuwać uszkodzenie mięśni szkieletowych definiowane jako wrażenie bólu mięśni szkieletowych z towarzyszącym podwyższonym poziomem kinazy kreatynowej w surowicy powyżej 200 U/l [14]. Rabdomioliza może być późnym powikłaniem zakażenia [25]. U pacjentów z objawami uszkodzenia mięśni zalecane jest badanie przesiewowe w kierunku zakażenia SARS-CoV-2. Oprócz aktywnego leczenia COVID-19, zalecana jest intensyfikacja wsparcia żywieniowego.

Neurolodzy mają pod opieką wielu pacjentów z takimi zespołami autoimmunologicznymi, jak stwardnienie rozsiane, myasthenia gravis czy zapalenie nerwu wzrokowego, stosujących różnorodne terapie immunosupresyjne. Należy zalecać takim pacjentom stosowanie dodatkowych środków ostrożności, aby zapobiec narażeniu na wirusa, ewentualnie ponownie przeanalizować dawki stosowanych leków immunosupresyjnych. Warto się zapoznać z zaleceniami opracowanymi przez grupę ekspertów Sekcji Stwardnienia Rozsianego i Neuroimmunologii Polskiego Towarzystwa Neurologicznego 
nology Section of the Polish Neurological Society, concerning the management of patients with multiple sclerosis using treatment affecting the natural course of the disease during the coronavirus pandemic, is recommended. Another group of neurological patients, which should introduce special safety measures are those with neurodegenerative diseases, i.e. Parkinson's disease or Alzheimer's disease. The pathological process already present in the nervous system may increase the risk of infection and its complications. Also, difficulties of access to specialists, medicines and rehabilitation, as well as the impact of isolation on the psyche in the times of pandemic should be considered, because all these factors may worsen the control of chronic diseases. In the present situation, tele-neurology may be an alternative for patients whose scheduled visits have been cancelled [26].

\section{Cerebrovascular accidents in patients with COVID-19}

Among patients with SARS-CoV-2 infection, strokes affected middle-aged and older people, particularly those whose condition was already critical. For some, it was their first in a lifetime stroke but many patients had cerebrovascular risk factors, such as hypertension, diabetes mellitus, hyperlipidemia or a history of previous stroke [12]. Patients with an acute cerebrovascular accidents with suspected or confirmed diagnosis of COVID-19 who become hospitalized should be treated jointly by neurologists and infectious disease specialists.

Patients with ischemic stroke who are treated thrombolytically or have undergone mechanical thrombectomy should be placed in isolation under close observation. It is recommended that hospitalization in general-access intensive care units should be avoided. Such patients should only be moved to a shared room when they show a normal body temperature for at least 3 days, normal results of routine blood tests and normal results of a CT scan of the chest as well as a negative molecular test for SARS-CoV-2 [6]. As already mentioned, SARS-CoV-2 specifically binds to ACE-2 receptors. Patients with hypertension may experience fluctuations in blood pressure after SARS-CoV-2 infection, which may put them at higher risk of an intracranial hemorrhage. Moreover, some critically ill patients with a SARSCoV-2 infection have severe thrombocytopenia, which is another high risk factor for cerebral hemorrhage [14]. For hypertensive patients with SARS-CoV-2 infection, it is recommended to stop using ACE inhibitors or angiotensin receptor antagonists as antihypertensives and consider, and introduce calcium channel blockers, diuretics or other classes of antihypertensive agents dotyczącymi postępowania z chorymi na stwardnienie rozsiane stosującymi leczenie wpływające na naturalny przebieg choroby w okresie pandemii koronawirusa. Inną grupą neurologicznych pacjentów są osoby z chorobami neurozwyrodnieniowymi, tj. chorobą Parkinsona czy chorobą Alzheimera. Tacy pacjenci powinni przestrzegać wszystkich środków bezpieczeństwa. Toczący się już proces patologiczny w układzie nerwowym może czynić ich szczególnie podatnymi na zakażenie i jego powikłania. Utrudniony dostęp do specjalistów i leków, brak rehabilitacji, wpływ odosobnienia na psychikę w czasach pandemii - wszystkie te czynniki mogą pogorszyć kontrolę chorób przewlekłych. W obecnej sytuacji teleneurologia może być alternatywą dla pacjentów, których planowe wizyty zostały odwołane [26].

\section{Incydenty naczyniowo-mózgowe u pacjentów z COVID-19}

Wśród pacjentów z zakażeniem SARS-CoV-2 udary dotyczyły osób w średnim i starszym wieku, szczególnie znajdujących się w stanie krytycznym. Dla części z nich to był pierwszy incydent udarowy. Wielu chorych miało inne czynniki ryzyka naczyniowo-mózgowego, takie jak nadciśnienie tętnicze, cukrzyca, hiperlipidemia lub wcześniej przebyty udar mózgu [12]. W przypadku hospitalizacji pacjenta z ostrym incydentem naczyniowym z podejrzeniem lub z potwierdzonym rozpoznaniem COVID-19 neurolodzy i specjaliści chorób zakaźnych powinni wspólnie przejąć opiekę nad chorym.

Pacjenci $\mathrm{z}$ udarem niedokrwiennym leczeni trombolitycznie lub po zabiegu trombektomii mechanicznej powinni przebywać na oddziale izolacyjnym pod ścisłą obserwacją. Zaleca się unikanie ich początkowej hospitalizacji na wspólnych oddziałach intensywnej opieki neurologicznej. W sytuacji prawidłowych wartości temperatury ciała (monitorowanie przynajmniej przez $3 \mathrm{dni}$ ), po uzyskaniu prawidłowych rutynowych badań krwi, prawidłowego wyniku tomografii komputerowej klatki piersiowej i ujemnego molekularnego testu w kierunku SARS-CoV-2, pacjenta można przenieść do pomieszczenia wieloosobowego [6]. Jak wspomniano, SARS-CoV-2 specyficznie wiąże się z receptorami ACE-2. U pacjentów z nadciśnieniem tętniczym mogą wystąpić fluktuacje ciśnienia krwi po zakażeniu SARS-CoV-2, co może zwiększać ryzyko krwotoku śródczaszkowego. Ponadto niektórzy krytycznie chorzy pacjenci z zakażeniem SARS-CoV-2 mają ciężką trombocytopenię, kolejny czynnik wysokiego ryzyka krwotoku mózgowego [14]. W przypadku pacjentów z nadciśnieniem tętniczym z zakażeniem SARS-CoV-2 zaleca się zaprzestanie stosowania inhibitorów ACE lub antagonistów receptora angiotensyny jako leków przeciwnadciśnieniowych oraz rozważenie wprowadzenia blokerów kanału wapniowego, diuretyków czy innych klas leków przeciwnadciśnieniowych [6]. W literaturze dostępne są opisy 
[6]. Cases of patients with cerebral encephalopathy in the course of SARS-CoV-2 infection can be found in the literature $[27,28]$.

\section{Infection of the central nervous system in patients with COVID-19}

During SARS-CoV-2 infection, some patients developed symptoms similar to those of encephalitis or meningitis, such as headaches, seizures and consciousness disorders. In several patients, these were preceded by respiratory symptoms [12]. In Japan, the first case of encephalitis in the course of COVID-19 was described in March 2020 [29]. On admission to the hospital, the patient was diagnosed with neck stiffness, and in the neurological assessment he scored 6 points on the Glasgow scale. A head NMR performed in the FLAIR sequence showed a hyperintense signal medially in the temporal lobe and in the hippocampus, which was slightly atrophied (the patient had no history of temporal epilepsy). Interestingly, the patient had a negative nasopharyngeal molecular test result, but SARS-CoV-2 infection in cerebrospinal fluid was already confirmed. Neurologists should therefore remain vigilant and in the case of patients with COVID-19 infection pay special attention to all symptoms that may suggest the beginning of an intracranial infection. In suspected cases, a contrast head MRI should be performed if possible. A lumbar puncture and SARS-CoV-2 nucleic acid test in cerebrospinal fluid using PCR are also recommended [6].

\section{CONCLUSIONS}

Elderly and immunocompromised patients are particularly sensitive to infections and at the same time they constitute a substantial group of neurological patients. The first symptoms of SARS-CoV-2 infection are usually similar to those of influenza. Approximately $80 \%$ of people who have COVID-19 do not require treatment and the disease disappears on its own. However, some of the patients with COVID-19 display new neurological symptoms which are very dangerous. In Italy, separate NeuroCovid wards have been established to attend to patients with neurological diseases and COVID-19. This strategy is also possible in Poland. Even in a person without a recognized nervous system disease, infection with SARS-CoV-2 may be associated with the risk of both acute and delayed neurological complications. Further observations are required for neurological disorders in patients infected with SARS-CoV-2. Intensive research is now underway to develop a safe and effective vaccine against SARS-CoV-2. pacjentów, u których w przebiegu zakażenia SARS-CoV-2 wystąpiła encefalopatia mózgu $[27,28]$, a jednym z przykładów jest ostra encefalopatia martwicza.

\section{Zakażenie ośrodkowego układu nerwowego u pacjentów z COVID-19}

W trakcie zakażenia SARS-CoV-2 u niektórych pacjentów wystapiły objawy podobne jak w przebiegu zapalenia mózgu czy zapalenia opon mózgowo-rdzeniowych, takie jak ból głowy, drgawki czy zaburzenia świadomości. U kilku pacjentów poprzedzały one wystąpienie objawów ze strony układu oddechowego [12]. W Japonii w marcu 2020 roku opisano pierwszy przypadek zapalenia mózgu w przebiegu COVID-19 [29]. U pacjenta przy przyjęciu do szpitala stwierdzono sztywność karku, w ocenie neurologa uzyskał 6 punktów w skali Glasgow. W wykonanym NMR głowy w sekwencji FLAIR opisano hiperintensywny sygnał przyśrodkowo $\mathrm{w}$ płacie skroniowym i w hipokampie $\mathrm{z}$ jego niewielkim zanikiem (pacjent bez wywiadu $\mathrm{w}$ kierunku padaczki skroniowej). Co ciekawe, u pacjenta uzyskano ujemny wynik testu molekularnego z nosogardła, ale potwierdzono już zakażenie SARS-CoV-2 w płynie mózgowo-rdzeniowym. Neurolodzy powinni zachować czujność, a u pacjentów zakażonych COVID-19 zwracać szczególną uwagę na wszystkie objawy mogące sugerować rozpoczynającą się infekcję wewnątrzczaszkową. W przypadkach podejrzanych, jeśli to możliwe, należy wykonać badanie MRI głowy z kontrastem. Zaleca się również nakłucie lędźwiowe i badanie na obecność kwasu nukleinowego SARS-CoV-2 w płynie mózgowo-rdzeniowym przy użyciu PCR [6].

\section{WNIOSKI}

Pacjenci w podeszłym wieku i z obniżoną odpornością są szczególnie wrażliwi na zakażenie, a jednocześnie stanowią znaczną grupę wśród pacjentów neurologicznych. Pierwsze objawy zakażenia SARS-CoV-2 sa zwykle podobne do objawów grypy. Około $80 \%$ osób, które chorują na COVID-19, nie wymaga leczenia, a choroba ustępuje sama. Okazuje się jednak, że u części pacjentów z COVID-19 zaobserwowano nowe, bardzo niebezpieczne objawy neurologiczne. We Włoszech utworzono osobne oddziały NeuroCovid, aby opiekować się pacjentami ze schorzeniami neurologicznymi i COVID-19. Taka perspektywa możliwa jest też w Polsce. Zakażenie SARSCoV-2 u osoby bez rozpoznanej choroby układu nerwowego może się wiązać z ryzykiem wystapienia zarówno ostrych, jak i opóźnionych powikłań neurologicznych. Wymagane są dalsze obserwacje pod kątem zaburzeń neurologicznych u pacjentów zakażonych SARS-CoV-2. Obecnie prowadzone sa bardzo intensywne badania w celu opracowania bezpiecznej i skutecznej szczepionki przeciw wirusowi SARS-CoV-2. 


\section{Conflict of interest/Konflikt interesu}

Absent./Nie występuje.

\section{Financial support/Finansowanie}

Absent./Nie występuje.

\section{References/Piśmiennicłwo}

1. Corman VM, Muth D, Niemeyer D, et al. Hosts and Sources of Endemic Human Coronaviruses. Adv Virus Res 2018; 100: 163-188.

2. Memish ZA, Perlman S, Van Kerkhove MD, et al. Middle East respiratory syndrome. Lancet 2020; 395: 1063-1077.

3. Zaki AM, van Boheemen S, Bestebroer TM, et al. Isolation of a novel coronavirus from a man with pneumonia in Saudi Arabia. N Engl J Med 2012; 367(19): 1814-1820.

4. Andersen KG, Rambaut A, Lipkin WI, et al. The proximal origin of SARS-CoV-2. Nature Medicine 2020; 26: 450-452.

5. Yong Z, Cao C, Shuangli Z, et al. Notes from the field: isolation of 2019- $\mathrm{nCoV}$ from a stool specimen of a Laboratory-Confirmed case of the coronavirus disease 2019 (COVID-19). China CDC Weekly 2020; 2: 123-124.

6. Jin H, Hong C, Chen S, et al. Consensus for prevention and management of coronavirus disease 2019 (COVID-19) for neurologists. Stroke \& Vascular Neurology 2020. DOI: 10.1136/ svn-2020-000382.

7. Yan R, Zhang Y, Li Y, et al. Structural basis for the recognition of the SARS-CoV-2 by full-length human ACE2. Science 2020; 367: 1444-1448.

8. Zhou P, Yang X-L, Wang X-G, et al. A pneumonia outbreak associated with a new coronavirus of probable bat origin. Nature 2020; 579(7798): 270-273.

9. Moralez G, Jouett NP, Tian J, et al. Effect of centrally acting angiotensin converting enzyme inhibitor on the exercise-induced increases in muscle sympathetic nerve activity. J Physiol 2018; 596(12): 2315-2332.

10. Nath A. Neurologic complications of coronavirus infections. Neurology 2020; 94: 1-2.

11. National Health Commission of the People's Republic of China. Chinese Clinical Guidance for COVID-19 Pneumonia Diagnosis and Treatment ( $7^{\text {th }}$ edition). 2020. (Accessed: 03.03.2020).

12. Mao L, Jin H, Wang M, et al. Neurological manifestations of hospitalized patients with COVID-19 in Wuhan, China. JAMA Neurol 2020 DOI: 10.1001/jamaneurol.2020.1127.

13. Hoffmann M, Kleine-Weber H, Schroeder S, et al. SARS-CoV-2 Cell Entry Depends on ACE2 and TMPRSS2 and Is Blocked by a Clinically Proven Protease Inhibitor. Cell 2020; 181: 271-280.

14. Guang WJ, Ni ZY, Hu Y, et al. Clinical Characteristics of Coronavirus Disease 2019 in China. N Engl J Med 2020. DOI: 10.1056/NEJMoa2002032.

15. Wu Z, McGoogan JM. Characteristics of and Important Lessons From the Coronavirus Disease 2019 (COVID-19) Outbreak in China: Summary of a Report of 72314 Cases From the Chinese Center for Disease Control and Prevention. JAMA 2020. DOI: 10.1001/jama.2020.2648.

16. Wang D, Hu B, Hu C, et al. Clinical Characteristics of 138 Hospitalized Patients With 2019 Novel CoronavirusInfected Pneumonia in Wuhan, China. JAMA 2020. 323(11): 1061-1069.

17. Hung EC, Chim SS, Chan PK, et al. Detection of SARS coronavirus RNA in the cerebrospinal fluid of a patient with severe acute respiratory syndrome. Clin Chem 2003; 49: 2108-2109.

18. Arabi YM, Harthi A, Hussein J, et al. Severe neurologic syndrome associated with Middle East respiratory syndrome coronavirus (MERS-CoV). Infection 2015; 43: 495-501.

19. Kim JE, Heo JH, Kim HO, et al. Neurological complications during treatment of Middle East respiratory syndrome. J Clin Neurol 2017. 13: 227-233.

20. Asadi-Pooya AA, Simani L. Central nervous system manifestations of COVID-19: A systematic review. J Neurol Sci 2020; 413: 116832 .

21. Yin R, Feng W, Wang T, et al. Concomitant neurological symptoms observed in a patient diagnosed with coronavirus disease 2019. J Med Virol 2020. DOI: 10.1002/jmv.25888.

22. Giacomelli A, Pezzati L, Conti F, et al. Self-reported olfactory and taste disorders in SARS-CoV-2 patients: a cross-sectional study. Clin Infect Dis 2020. DOI: 10.1093/cid/ciaa330.

23. ENT UK. Loss of sense of smell as marker of COVID-19 infection (Accessed: 30.03.2020).

24. Xu H, Zhong L, Deng J, et al. High expression of ACE2 receptor of 2019-nCoV on the epithelial cells of oral mucosa. Int J Oral Sci 2020; 12: 8.

25. Jin M, Tong Q. Rhabdomyolysis as potential late complication associated with 2019 novel coronavirus disease. Emerg Infect Dis 2020; 20: 26(7).

26. Majersik JJ, Reddy VK. Acute neurology during the COVID-19 pandemic: Supporting the front line. Neurology 2020. DOI: $10.1212 /$ WNL.0000000000009564.

27. Poyiadii N, Shahin G, Noujaim D, et al. COVID-19-associated Acute Hemorrhagic Necrotizing Encephalopathy: CT and MRI Features. Radiology 2020. https://pubs.rsna.org/doi/10.1148/radiol.2020201187.

28. Filatov A, Sharma P, Hindi F, et al. Neurological Complications of Coronavirus Disease (COVID-19): Encephalopathy. Cureus 2020; 12(3): e7352. DOI: 10.7759/cureus.7352.

29. Moriguchia T, Hariib N, Gotoa J, et al.: A first case of meningitis/encephalitis associated with SARS-Coronavirus-2. International Journal of Infectious Diseases 2020; 94: 55-58. 